\title{
CLOSING OF SCHOOLS AND REDISTRIBUTION OF TEACHING STAFF: CASE STUDY OF THE MUNICIPALITY OF NOVA VAROŠ
}

\author{
Slavoljub Jovanovićt \\ "University of Belgrade - Faculty of Geography, Belgrade
}

\begin{abstract}
This research examined the redistribution of teaching staff in the Municipality of Nova Varoš in the last 25 years. The aim of this paper was to determine the number of teachers who were redistributed in the mentioned period and whether this was influenced by the closing of schools and the decrease in the number of schools. The results were obtained on the basis of data analysis from the Annual Work Plans of Schools in the Municipality of Nova Varoš and the Special Collective Agreements for employees in primary and secondary schools. The results of the research indicate that the optimization of the school network, based on the current state and demographic trends, will go towards the unification of small schools.
\end{abstract}

Key words: GIS Nova Varoš, teaching staff, redistribution, closing of schools.

\section{Introduction}

Spatial distribution, number, type and structure of educational institutions in a certain territory are regulated by the Act on the Network of Institutions. The Act on the Network of Primary Schools is passed by the Assembly of the local self-government unit, on the basis of the criteria prescribed by the Government of the Republic of Serbia. The Ministry of Education, Science and Technological Development approves the Act on the Network of

${ }^{1}$ Corresponding author: S. Jovanović, University of Belgrade - Faculty of Geography, Studentski trg 3/III, 11,000 Belgrade, Serbia; e-mail: slavoljub1@gmail.com 
Primary Schools. If the competent authority of a local self-government unit fails to issue the Act on the Network of Primary Schools, the Ministry determines the deadline for its adoption; in the event that the deadline is not respected, the Ministry shall adopt the Act on the Network of Primary Schools (Official Gazette of the Republic of Serbia, 80/2010).

The Act on the Network of Primary Schools has the character of a planning document, which, in addition to respecting the relevant natural and social factors, designs the development and functioning of the educational system in a certain territory. In principle, a local self-government unit shows interest in timely drafting of this document, because in this way it enables access to education, plans working posts, revises local traffic lines, rationalizes the cost of transportation of teachers and children, maintenance of facilities and surfaces, energy products, electricity and investments. On the other hand, the desirable scenario emphasizes the active role of a local selfgovernment unit for a detailed knowledge of the specifics of a certain territory; the role of the Ministry is specified only as the ultimate instance, if the agreement cannot be reached at the local level. The Act on the Network of Primary Schools ceases to be valid if status or other changes of significance occur, and the organization and realization of educational work does not coincide with the projected one. Most often situations are when certain satellite sub-schools of a base school are closed, a four-grade or eight-grade school, which immediately implies the creation of a new act.

\section{Research methodology}

The aim of the research was to determine the number of teachers who had been redistributed in schools in the Municipality of Nova Varoš in the last 25 years and to determine the factors of such a situation. In this paper, a descriptive method was introduced, which included an analysis of the Annual Work Plans of Schools in the Municipality of Nova Varoš and the Special Collective Agreements for employees in primary and secondary schools. Redistribution of teaching staff in schools in the Municipality of Nova Varoš was brought into connection with closing of schools and reducing the number of pupils. In the wider context of considering these causes, the following was observed:

- accessibility and equality of the right to education and upbringing and involvement of children and pupils by compulsory education; 
- rationality, territorial equity, efficiency, effectiveness and economy of work organization;

- demographic and economic indicators and trends (total population of children of a certain age, population growth, population migration, population of national minorities, local tradition, level of economic development of the municipality);

- geographical (characteristics of relief and climate, size, mutual distance and traffic connection of the settlements, border area) and ecological factors.

\section{Modification of the network of primary schools in the Municipality of Nova Varoš}

The Act on the Network of Primary Schools in the Municipality of Nova Varoš was adopted in 2016. This document specifies that educational work is organized at the level of 6 elementary schools (base schools) and 13 satellite subschools. In the school year of 2016/17, there were 1,039 pupils distributed in 74 classes. The ratio of the number of pupils attending classes in the only town school (PS "Živko Ljujić") in relation to the number of pupils in rural schools and the distance of satellite sub-schools from base schools are given in Table 1.

The only town primary school is attended by $73 \%$ of pupils in the municipality. In addition to the base schools that are eight-grade, only the SS Negbina is an eight-grade school (13 pupils in the subject teaching), while the remaining satellite sub-schools are four-grade schools. Except for the town school, all other schools organize class teaching (one teacher education) in combined classes from the 2 nd to the 4 th grade. The nearest satellite sub-school is located $4 \mathrm{~km}$ from the base school, and the most distant one is $17 \mathrm{~km}$. The minimum number of pupils in rural schools in single-level classes is 2 , and the maximum is 17 . 
Table 1 - Number of pupils, classes and structure of primary schools in the Municipality of Nova Varoš

\begin{tabular}{|c|c|c|c|c|}
\hline $\begin{array}{l}\text { Name of school } \\
\text { and location }\end{array}$ & $\begin{array}{l}\text { Base school and } \\
\text { satellite sub- } \\
\text { schools (SS) } \\
\end{array}$ & $\begin{array}{c}\text { Distance } \\
\text { from the base } \\
\text { school }(\mathrm{km})\end{array}$ & $\begin{array}{l}\text { Number } \\
\text { of pupils }\end{array}$ & $\begin{array}{l}\text { Number } \\
\text { of classes }\end{array}$ \\
\hline \multirow{5}{*}{$\begin{array}{l}\text { PS “Momir } \\
\text { Pucarević", } \\
\text { Akmačići }\end{array}$} & Base school & 0 & 39 & 5 \\
\hline & SS Radijevići & 5 & 2 & 1 \\
\hline & SS Drmanovići & 7 & 6 & 1 \\
\hline & SS Vilovi & 8 & 3 & 1 \\
\hline & Total & & 50 & 8 \\
\hline $\begin{array}{l}\text { PS "Dobrisav } \\
\text { Dobrica Rajić", } \\
\text { Bistrica }\end{array}$ & Base school & 0 & 26 & 6 \\
\hline \multirow{3}{*}{$\begin{array}{l}\text { PS "Knezova } \\
\text { Raškovića”, } \\
\text { Božetići }\end{array}$} & Base school & 0 & 38 & 6 \\
\hline & SS Ljepojevići & 7 & 10 & 1 \\
\hline & Total & & 48 & 7 \\
\hline \multirow{5}{*}{$\begin{array}{l}\text { PS "Vuk Stefanović } \\
\text { Karadzić", } \\
\text { Jasenovo }\end{array}$} & Base school & 0 & 25 & 5 \\
\hline & SS Gornja Bela Reka & 10 & 3 & 1 \\
\hline & SS Donja Bela Reka & 10 & 6 & 1 \\
\hline & SS Kućani & 7 & 3 & 1 \\
\hline & Total & & 37 & 8 \\
\hline \multirow{6}{*}{$\begin{array}{l}\text { PS “Gojko } \\
\text { Drulović", } \\
\text { Radoinja }\end{array}$} & Base school & 0 & 65 & 5 \\
\hline & SS Negbina & 11 & 20 & 5 \\
\hline & SS Kokin Brod & 6 & 10 & 1 \\
\hline & SS Rutoši & 6 & 11 & 2 \\
\hline & SS Draglica & 17 & 3 & 1 \\
\hline & Total & & 109 & 14 \\
\hline \multirow{3}{*}{$\begin{array}{l}\text { PS “Živko Ljujić”, } \\
\text { Nova Varoš }\end{array}$} & Base school & 0 & 763 & 31 \\
\hline & SS Draževići & 4 & 6 & 1 \\
\hline & Total & & 769 & 31 \\
\hline \multicolumn{3}{|c|}{ Total municipalities of Nova Varoš } & 1,039 & 74 \\
\hline
\end{tabular}

Legend: SS - satellite sub-school

Sources: Annual Work Plan, PS “Knezova Raškovića”, Božetići, 2016; Annual Work Plan, PS "Momir Pucarevic", Akmačići, 2016; Annual Work Plan, PS “Dobrisav Dobrica Rajić", Bistrica, 2016; Annual Work Plan, PS “Vuk Stefanović Karadzić”, Jasenovo 2016; Annual Work Plan, PS “Gojko Drulović”, Radoinja, 2016; Annual Work Plan, PS “Živko Ljujić”, Nova Varoš, 2016. 
In the last 25 years, the network of schools in the Municipality of Nova Varoš has been changed only by closing of the satellite sub-schools. The main reason for closing is the lack of pupils. The trend of the 1970s, when local selfgovernment units prescribed the required minimum number of pupils for the survival of the satellite sub-schools, was not properly figured in the Municipality of Nova Varoš out of justified reasons. The decisive factors in the decisions of the Municipal Assembly include the following: the great mutual distance of the villages, the lack of roads, the inaccessibility of certain villages during winter, heavy snowfall, the safety of pupils transport. Under such conditions, the availability of education was ensured by maintaining satellite sub-schools with a minimum number of pupils. The impact of the school on the life of the village is still perceived as very important, and the cessation of school work is postponed as much as possible (Hargreaves, 2009; Smith, Beihammer and Raggl, 2015). “The departure of teachers and the closing down of the school is a sign that the village, as a social community, is near to its end, that the social community gave it to the mercy of the quiet dying." (Трнавац, 1992). So, we are not just talking about physical moving away of a school from pupils or villagers, but also about the kind of psychological effect that closing of the school has on the community. The lack of teachers, as the bearer of educational and cultural influence, impacts both children and adults (Špijunović, 1981).

In the aforementioned period, the following schools were closed on the territory of the Municipality of Nova Varoš:

- SS Štitkovo, PS “Knezova Raškovića”, Božetići, 2013;

- SS Donja Bistrica, PS “Dobrisav Dobrica Rajić”, Bistrica, 2010;

- SS Miševići, PS “Momir Pucarević”, Akmačići, 2002;

- SS Amzići, PS “Živko Ljujić”, Nova Varoš, 1993;

- SS Sjeništa, PS “Gojko Drulović”, Radoinja, 1993.

At the same time, efforts were made to modernize teaching and provide better school resources in the remaining schools, through the investment of the Ministry, the local self-government unit and the donation. Due to the professional involvement of the teaching staff and the possibilities of cooperation with other departments, PS "Živko Ljujić" is distinguished in the municipality as a school that constantly enriches educational offer and support for the pupils. The psycho-pedagogical service of the school is engaged as a support to kindergarten and village schools. By the development of the pupil inclusion programme with the need for additional support and a new approach to the 
professional orientation of pupils, schools can improve their quality of education and upbringing (Vujadinović et al, 2013; Ingersoll and Collins, 2017).

\section{Redistribution of teaching staff as a result of changing the school network}

Alteration in the network of schools causes the changes in the employed teaching staff status. The closing of four-grade schools generates a technological surplus, whereby employed teachers remain undistributed; the closing of eight-grade schools, leaves teachers without a part of the norm, thus earning the status of part-time employees. At the level of the institution (school), the identification of employees whose work has ceased to be necessary based on the criteria prescribed by the Special Collective Agreement (SCA, 2015), is done. Both groups of employees acquire the right to take over, by placing them on the list of employees from which the takeover takes place. The list is formed at the level of school administration, by units of local self-government (Official Gazette of the Republic of Serbia, No. 72/2009, $52 / 2011,55 / 2013)$. Teachers who realize classes in closed schools are not included in the list, but they are scored together with other colleagues, at school level, and then the total or partial redundancy of employees is determined. The right to take over is carried out within the lost norm, first in the territory of the municipality, and then the school administration. A Special Collective Agreement also provides for the possibility of taking over between different school administrations; it is important to emphasize that it is necessary for the employee to agree with the takeover plan, or to seek the best possible solution for the employee, taking into account the place of residence, the traffic line, the weekly fund of classes (per subjects). By establishing a unique information system "Dositej", the active role of teachers in the process of takeover has been emphasized. All available jobs are visible, and the teacher launches an initiative to take over; the takeover agreement is signed by the school principals and the employees themselves.

Closing of satellite sub-schools does not only influence the formation of a technological surplus of teaching staff. The percentage of engagement of professional associates, accountants and support staff also depends on the number of classes at the institution level. Therefore, the non-teaching staff exercises the same rights in the takeover procedure as well as the teaching staff. Furthermore, each school year marks a decrease in the number of classes due to the negative population growth and emigration of the population 
Closing of Schools and Redistribution of Teaching Staff: Case Study of the Municipality of Nova Varos

from the Municipality of Nova Varoš. The technological surplus generated in schools in this way far outstrips the number of teachers who remain without a part of the norm or working post due to the closing of schools. In this paper we will explain the working status of teachers who worked in closed schools, but we will also take into account the teachers who were in the same position due to the decrease in the number of classes.

By closing the satellite sub-schools in the last 25 years, five teachers remained without working posts. While one teacher fulfilled the retirement requirement, one teacher was temporary employed, and his contract was not extended; one teacher changed his profession, while the other two teachers were employed in the territory of the municipality: one teacher in the same institution (base school or other satellite sub-school), and one teacher in another school in the municipality.

Table 2 - Movement of the number of pupils in the Municipality of Nova Varoš in the period $2006-2016$

\begin{tabular}{|c|c|c|c|c|c|c|c|}
\hline \multirow{2}{*}{ Year } & \multicolumn{6}{|c|}{ School } & \multirow{2}{*}{ Total } \\
\hline & 1 & 2 & 3 & 4 & 5 & 6 & \\
\hline 2006 & 81 & 43 & 66 & 63 & 181 & 984 & 1,418 \\
\hline 2007 & 82 & 41 & 61 & 57 & 166 & 968 & 1,375 \\
\hline 2008 & 72 & 38 & 57 & 60 & 158 & 926 & 1,311 \\
\hline 2009 & 62 & 32 & 59 & 45 & 146 & 880 & 1,224 \\
\hline 2010 & 58 & 25 & 54 & 43 & 132 & 875 & 1,187 \\
\hline 2011 & 58 & 25 & 52 & 46 & 132 & 865 & 1,178 \\
\hline 2012 & 59 & 28 & 46 & 41 & 128 & 845 & 1,147 \\
\hline 2013 & 51 & 27 & 44 & 42 & 121 & 838 & 1,123 \\
\hline 2014 & 60 & 28 & 43 & 36 & 117 & 806 & 1,090 \\
\hline 2015 & 51 & 30 & 47 & 40 & 109 & 784 & 1,061 \\
\hline 2016 & 50 & 26 & 48 & 37 & 109 & 769 & 1,039 \\
\hline
\end{tabular}

Legend: 1. PS "Momir Pucarević", Akmačići; 2. PS "Dobrisav Dobrica Rajić", Bistrica; 3. PS "Knezova Raškovića”, Božetići; 4. PS "Vuk Stefanović Karadzić", Jasenovo; 5. PS “Gojko Drulović", Radoinja; 6. PS “Živko Ljujić”, Nova Varoš.

Sources: Annual Work Plan, PS “Knezova Raškovića”, Božetići, 2016; Annual Work Plan, PS "Momir Pucarević", Akmačići, 2016; Annual Work Plan, PS “Dobrisav Dobrica Rajić", Bistrica, 2016; Annual Work Plan, PS “Vuk Stefanović Karadzić", Jasenovo 2016; Annual Work Plan, PS “Gojko Drulović”, Radoinja, 2016; Annual Work Plan, PS “Živko Ljujić”, Nova Varoš, 2016. 
In the last 10 years, the number of primary school pupils has decreased by 379 (see Table 2), which corresponds to the number of about 13 classes of the average town school. In the Municipality of Nova Varoš, only one school can be considered as such school in terms of resources and organization of work - all other schools are rural, with an average number of pupils in classes not exceeding 10 . Therefore, in practice, it is a loss of a significantly larger number of classes than at first glance. In the last 10 years, the Municipality of Nova Varoš has recorded a decrease in the number of pupils exceeding the total number of all pupils in rural schools.

The projected decrease in the number of pupils in rural schools is not entirely due to emigration and decrease in the population growth. A part of the pupils who gravitate, according to their place of living in rural schools, attend classes at the PS "Živko Ljujić" in Nova Varoš. Parents employed in Nova Varoš give priority to the town school, which is farther away from the nearest village school. There are several reasons for this. In winter, more important road directions are maintained, that is, the roads to the municipal centre, and this is not valid for the rural roads leading to the school. According to Annual Work Plans of the Schools, about $60 \%$ of pupils from rural schools walk 3-5 $\mathrm{km}$ to school, and $20 \%$ walk $5-10 \mathrm{~km}$. The organization of work of the village school faces problems that result in a poorer quality of pupils' education. Due to a small percentage of work engagement within the school, the subject teachers work in 3 or 4 distant schools. In this way, it is impossible to create schedules of classes that meet pedagogical requirements, and classes of foreign languages, chemistry, physics and biology are held in the block, that means on the same day. Teachers do not spend enough time, that is, working days in a certain school, in order to be able to give their full contribution to the work of school teams, or to implement learning support programmes, as well as the areas of quality of Pupil Achievement and Support to Pupils remain at a lower level than in a town school. For the same reason, the offer of extracurricular activities is narrowed, according to human resources. By the previous school year, most rural schools did not have professional associates, while the town school had a psychologist, pedagogue and oligophrenologist. Pupils with the need for additional support, especially in the older classes, progress poorly without professional help and continuity in work, which rural schools were not in a position to offer. The offer of another foreign language is limited to only one (Russian), even though this item is not professionally represented. The realization of the content of information and computing is on a lower level, due to weaker equipment and interruptions in the supply of electricity in the cooler period of the year. Lack of cabinet teaching and teaching materi- 
als determines the quality of teaching of physics, chemistry, geography and biology. Although the assessment of the quality of school work through the external evaluation of the quality of the work of the institution is contextualized, it therefore takes into account the specificities of local environment and school resources (Birdsall, Levine, Ibrahim, 2005; Anthony, Hunter, Hunter, 2015); it confirms the poorer quality of all school work in rural conditions.

Over the past 10 years, about 40 teachers have been redistributed at the municipal level for the entire or part of the norm. Natural shift of teaching staff depreciated one part of the loss of pupils. In the previous school year of 2016/17, 14 teachers in the Municipality of Nova Varoš were on the takeover list: two teachers were taken to institutions in the territory of the municipality, one teacher was taken over in the territory of another municipality, one teacher was taken over in the territory of the second school administration, for four teachers a temporary solution was found (replacement of teachers who were on long sick leave, incompetent classes); there were no solutions for other teachers, and they were still on the takeover list. At the same time, from the territory of the Municipality of Prijepolje, three teachers, one expert associate and one accountant worker were employed in schools of the Municipality of Nova Varoš.

\section{Optimization of the network of primary schools in the future}

The local self-government unit is obliged, prior to the drafting of the Act on the Network of Primary Schools, to prepare a study on demographic indicators in order to find more rational solutions regarding the organization of education and upbringing. A Network Development Plan is being developed for a period of 4 to 8 years, which provides solutions for the established natural and mechanical movement of the population in the territory of the municipality. The situation in education is viewed even wider, in terms of the movement of children and pupils through preschool, primary and secondary schools. The coverage of children by preschool education and education is the lowest in the Municipality of Nova Varoš when the data for the Zlatibor district are examined and it is around $5 \%$. This results in a late diagnosis of psycho-physical developmental problems and learning difficulties, delayed peer socialization and the formation of adequate habits. In the secondary schools, 4 classes of pupils are enrolled: natural-mathematical and social-language course in the Gymnasium and mechanical technician of motor vehicles and tourist technician in the Technical school. The narrow offer of educational profiles results in the outflow of completed primary 
schools into medical and construction profiles (Užice), catering (Čajetina) and economic (Prijepolje). Three-year schooling is not offered, and students who have not scored 50 points on the basis of success and final exam, have no alternative if they want to continue their education.

For the Municipality of Nova Varoš, there is a certain number of satellite sub-schools that currently number 2-3 students. At the same time, the optimization of the network of schools will, according to the current situation and demographic trends, go towards the unification of small schools. In this way, the school does not cease to exist; it continues to work, represents the educational and cultural core of the village, nurtures and teaches about local traditions, warns and prevents the difficulties of childhood and paves the way for the development and promotion of children. Working posts of managers, professional associates and accountants are being rationalized, and savings are achieved in a way acceptable to both pupils and teachers. Serious work on increasing the involvement of children by preschool education and upbringing in the rural environment can contribute to the prevention of the abandonment of villages by young families and the preservation of rural schools in the municipality.

\section{Conclusion}

In the last 25 years, the network of schools in the Municipality of Nova Varoš has been changed only by closing of the satellite sub-schools. The main reason for closing schools in the villages is the lack of pupils. In the last 10 years, the Municipality of Nova Varoš has recorded a decrease in the number of pupils that exceeds the total number of all pupils in the rural schools. The main causes are the following: large inter-village distances, lack of roads, inaccessibility of certain villages during winter, heavy snowfall, safety of pupils transport. Changes in the status of the employed teaching staff result from the change in the network of schools. The closing of fourgrade schools generates a technological surplus, whereby employed teachers remain undistributed; by closing of eight-grade schools, teachers remain without a part of the norm, thus earning the status of part-time employees. By closing the satellite sub-schools in the last 25 years, 5 teachers have remained without a working post. In the last 10 years, about 40 teachers have been redistributed at the municipal level for a whole or a part of the norm. Optimization of the network of schools should be aimed at bringing together small schools. In this way, the school would continue to work and represent the educational and cultural core of the village. 


\section{Acknowledgements}

The paper is the result of the research within the project no. 176008 funded by the Ministry of Education and Science of the Republic of Serbia.

\section{References}

Anthony, G., Hunter, J., and Hunter, R. (2015). Prospective Teachers Development of Adaptive Expertise. Teaching and Teacher Education, 49(7), 108-117.

Birdsall, N., Levine, R. And Ibrahim, A. (2005). Towards universal primary education: Investments, incentivesand institutions. European Journal of Education, 40(3), 337-349.

Hargreaves, L., M. 2009. Respect and Responsibility: Review of Research on Small Rural Schools in England, International Journal of Educational Research, 48(2). 117-128.

Ingersoll, R. M., and Collins, G. J. 2017. Accountability and Control in American Schools. Journal of Curriculum Studies, 49(1), 75-95.

Poseban kolektivni ugovor za zaposlene u osnovnim i srednjim školama i domovima učenika. (2015). Br. 110-00-334/2014-01. Beograd.

Smit, R., Beihammer, E. K. H., and Raggl, A. 2015. Teaching and Learning in Small, Rural Schools in Four European Countries: Introduction and Synthesis of Mixed-/Multi-Age Approaches. International Journal of Educational Research, 74(1), 97-103.

Špijunović, K. (1981). Organizacija rada u kombinovanom odeljenju, Beograd: Institut za pedagogiju i andragogiju Filozofskog fakulteta.

Vujadinović, S, Šabić, D. Joksimović, M., Golić, R., Živković, Lj, Gatarić, D. (2013). Asylum seekers from Serbia and problems of returnees: Why Serbia is among the worlds leading countries in number of asylum seekers. Dve domovini, razprave o izseljenstou, 37, 53-68.

(2009). Law on the Education System, Official Gazette of the Republic of Serbia, no. 72 .

(2010). Act on the Network of Primary Schools, Official Gazette of the Republic of Serbia, no. 80.

(2011). Law on Changes and Additions to Law on the Education System, Official Gazette of the Republic of Serbia, no. 52. 
(2013). Law on Changes and Additions to Law on the Education System, Official Gazette of the Republic of Serbia, no. 55.

Трнавац, Н. (1992). Мале сеоске школе. Београд: Институт за педагогију и андрагогију Филозофског факултета. 